\section{Geological Society Elections}

THE following have been elected foreign members and foreign correspondents of the Geological Society of London: Prof. R. A. Daly, Sturgis Hooper professor of geology in the Museum of Comparative Zoology at Harvard College, an authority on igneous rocks and mountain building and on coral reefs; Prof. Paul Niggli, University of Zurich, distinguished for his work on ore deposits and crystallography; and Prof. Bailey Willis, Stanford University, known for his work on geological structures, to be foreign members of the Society. Prof. C. P. Berkey, Columbia University, New York City, secretary of the Geological Society of America, who has carried out geological studies in Mongolia and elsewhere; Prof. H. A. Brouwer, University of Amsterdam, known for his work on the geology and petrology of the Dutch East Indies; Prof. Hans Cloos, University of Bonn, an authority on the tectonics of igneous intrusions; Prof. W. K. Gregory, curator in the American Museum of Natural History, New York City, distinguished for his studies on fossil vertebrates ; and Dr. Victor Van Straelen, director of the Natural History Museum in Brussels, distinguished for his work on fossil Crustacea, to be foreign correspondents of the Society.

\section{Beilby Memorial Awards}

Awards are made from time to time from the interest on the Beilby memorial fund to British investigators in science for original work, preference being given to the investigation of problems connected with fuel economy, chemical engineering, and metallurgy. The administrators of the fund have just awarded $£ 105$ each to Mr. W. J. Rees, of the Department of Applied Science in the University of Sheffield, and Dr. W. R. Schoeller, metallurgist, Messrs. D. C. Griffith and Co., London. Mr. Rees was educated at George Dixon Technical School, Birmingham, and at the Royal College of Science, London. In 1901, he became assistant to Dr. Walter Rosenhain, in the laboratories of Messrs. Chance Bros. and Co., Ltd., at Birmingham; in 1906-17, he was chief chemist to the same company, and since 1917 he has been lecturer in charge of the Department of Refractory Materials in the University of Sheffield. $\mathrm{He}$ is an honorary member of the British Cast Iron Research Association, to which he was elected in recognition of services rendered in connexion with research on moulding sands; and hon. secretary of the Refractories Association of Great Britain. Dr. Schoeller was born at Antwerp and educated in Belgian State schools at Antwerp and Tournai. He studied chemistry at the Polytechnic Institutes at Darmstadt and Stuttgart, and at the University of Greifswald, where he obtained the degree of Ph.D. in 1902. In the following year, he joined the staff of Messrs. D. C. Griffith and Co., assayers to the Bank of England, and in 1909 was naturalised as a British subject. After experience in the United States, South America, China, and elsewhere, he rejoined Messrs. D. C. Griffith and Co., specialising in rare metals. From 1913 onwards, he has devoted much of his spare time to original research work, especially on tantalum and niobium.
He is joint author with Mr. A. R. Powell, of "The Analysis of Minerals and Ores of the Rarer Elements".

\section{The Peking Man}

Aт a meeting of the Geological Society of China on June 28, Prof. Davidson Black made the first public reference to the discovery of parts of Sinanthropus other than the skull--an ungual phalanx of the foot found more than two years ago, a clavicle and a semilunar bone (wrist) found last season. The announcement of these discoveries was withheld until the close of the present season's excavations at Chou Kou Tien in the hope that other parts of the limbs might be recovered. This hope has not been realised. Hence an account is now given of the small fragment that seems to demonstrate that the Peking man's hand "differed in no essential respect from our own", of the peculiar obliquely-directed toe-bone, which " makes it probable that the feet differed much more widely from ours than the hands ", and of the robust clavicle. On July 5 Prof. Davidson Black left Peking for England to deliver the Croonian Lecture to the Royal Society next December; he is visiting fossil beds in India and Egypt on the way. Before leaving China. he made casts of the five jaw fragments, the complete skull of the youth found in 1929, and of the endocranial cast of Sinanthropus, for transmission to London for reproduction, and completed his report on the endocranial cast and its significance. Its capacity is not more than 900 c.c. It reveals the asymmetry claimed to be distinctive of right-handedness. The cast displays many primitive features of exceptional interest, which shed important light on the distinctive characters of the earliest human brain.

\section{Women Graduates in Modern Life}

$\mathrm{AT}_{\mathrm{T}}$ the annual reunion on June $\mathbf{3 0}$ of the University of Edinburgh Graduates' Association, held in the Women's Union, Sir Josiah Stamp referred to the alumni associations in America as constituting one of the strongest sides of American university life, and said that he hoped the graduates of Edinburgh would similarly endeavour to make the University a real and active part in themselves, letting its influence remain with them and helping it in every way they could. Speaking more particularly to the women graduates, he reflected upon the gravity of the times in which we live and the tremendous importance and value of the collective mental training represented by the graduates who had just been ' capped', mobilised and conserved for the future. While it may be said that the careers of many of these women will be cut short and some people may say all they have done at the University would so be wasted, he considers that a wrong view. Why should not man and wife act together in the great task of thinking out the world's problems, thus making for a higher standard of civic and individual judgment than we have to-day?

\section{The Universities and Civilisation}

SIr JosiaH was emphatic that civilisation is at the crossroads ; it may go one way under the influence of mass desire and mass impression, or the other way under the influence of intellectual and moral leader-

No. 3271 , Vor. 130$]$ 
ship. If a university is not a great force, if the members of a university are not a great force in that decision, then who is ? Where are we to look for it ? In this crisis in civilisation there is a terrific responsibility on university graduates for elasticity of mind, probity and clarity of judgment, and industry of thought on the concrete issue before them. There are many great issues on moral principles in these days, when the widely-held view is that the proper place for a path is the edge of the precipice. The world is full of good people who are thoroughly muddle-headed; this is a time for level-headed decisions and carefully worked out ones. Sir Josiah concluded with a call to the students to be true to the great ideals the university has given them; and to try to make the university what he believes it ought always to be--somewhere where the reasoned thought and soul of our country can have the perpetual association of great ideas, the discipline of serious and persistent aims, the purification of candid and purging humour, and lastly the company of souls that are kindled to noble purposes.

\section{Society for Psychical Research}

THE last of the jubilee meetings of the Society for Psychical Research was held on July 4 at the Conway Hall, when Dr. William Brown, Wilde reader in mental philosophy in the University of Oxford, lectured on "Psychology and Psychical Research". The president, Sir Oliver Lodge, took the chair. Dr. Brown said that hypnotic and psycho-analytic investigations have greatly supplemented the theory of the 'subliminal self' first propounded by F. W. H. Myers, one of the founders of the Society for Psychical Research, without, however, really supplanting it. The employment of the statistical method on large numbers of cases is entirely in the spirit of strict science, yet the predominantly negative results recently obtained along these lines as regards manifestations of telepathy and clairvoyance should not blind the public to the possibility of such phenomena in special cases and under special conditions. The intensive study of well-attested individual cases is needed to correct the balance, and it is especially along this line that the Society for Psychical Research has done much useful work. One might base one's belief in survival most firmly on general philosophical and religious considerations as to the nature and value of human experience; nevertheless, the sum total of evidence of a scientific nature accumulated by the Society for Psychical Research in support of survival is far from negligible.

\section{Marconi Beam Stations for Shanghai}

New Marconi transmitting and receiving stations are to be erected near Shanghai for the operation of the proposed short-wave beam services between China and Europe and the United States. A unique feature of the installation will be the inclusion of auxiliary Marconi apparatus enabling the transmitters to be utilised for broadcasting services when they are not in use for telegraphic communications. The auxiliary apparatus for this purpose consists of a modulating equipment which can be connected to either of the telegraph transmitters to provide telephone signals of broadcasting quality. A complete set of Marconi studio equipment is also to be supplied to enable the service to be conducted in accordance with the most modern practice. The aerial system of the transmitting station is of particular interest. For the commercial telegraph services to Europe, of which the principal is the service to Great Britain, two bays of beam aerials, accurately oriented to concentrate their signals on the receiving stations, are to be erected, one being tuned to the wave-length of 17 metres and the other to 26 metres, the wave-lengths allotted to these circuits. A third beam aerial array will be directed on San Francisco for the American service. In addition, there will be four omni-directional aerials, one of which will be used for broadcasting. The others are provided to afford the station the maximum flexibility in the range and extent of its telegraphic services. At the receiving station four high-speed commercial service receivers of the Marconi beam type are to be installed, with two beam aerial systems directed on Europe and two on San Francisco. Four omni-directional receiving aerials are also to be supplied for the reception of short-wave signals from other countries with which beam services are not required. On the completion of these stations near Shanghai a direct commercial wireless circuit will be provided for the first time between Great Britain and China.

\section{Emergency Lighting Sets}

IN addition to the usual source of electric power for supplying lamps and signalling devices, it is somet imes necessary, in order to safeguard life and property, to have another source of power that can be available in emergency. Such additional sources are necessary for theatres, cinemas, hospitals, and for all large buildings through which there is a continuous stream of traffic. Up to the present time, storage batteries have often been used for this purpose, but their drawbacks are their expense and the gases they develop, often necessitating the use of a large separate room. A petrol electric set has sometimes been suggested, but there is frequently difficulty in starting it after a long period of standstill. Fire risks also impose restrictions in the selection of rooms for these sets. In a recent issue of Allgemeine Elektricitäts Gesellschaft (A.E.G.) Progress, a new emergency lighting set is described which eliminates practically all these difficulties. It consists simply of a small water turbine, which can be connected to the municipal water mains and drives a direct current generator (turbinamo). The water supply to the turbine is normally cut off. Should the normal supply voltage fall for any reason, an electro-magnet ceases to act and so a cut-off device is released, and the pressure of the water in the mains opens a valve and the machine rotates. The water pressure required is anything between 3 and 6 atmos. $(42 \cdot 5-85 \mathrm{lb}$. per sq. in.). The lighting set has a vertical axis, and takes up very little space. It should be placed near the water supply mains. As a disturbance rarely occurs, and lasts only very little time, the cost of the water used is negligible.

No. 3271, VoL. 130] 